\title{
ANALISIS PERANAN AUDIT MUTU INTERNAL SEBAGAI ALAT BANTU DALAM MENUNJANG EFEKTIVITAS MANAJEMEN PADA STMIK STIKOM INDONESIA
}

\author{
Oleh \\ Ayu Gede Willdahlia \\ STMIK STIKOM Indonesia \\ willdahlia@yahoo.com
}

Diterima 21 Juli 2017, direvisi 02 Agustus 2017, diterbitkan 31 Agustus 2017

\begin{abstract}
Educational institutions are one of the growing organizations with the complexity of existing problems. Started from applying Tri Darma Perguruan Tinggi, where lecturers are required to be able to carry out teaching activities, research and dedication to the sustainable society every year. In addition to the activities undertaken in campus environment as a whole that already underway requires an evaluation conducted to maintain the quality. In addition, management also requires and goals to be achieved. A tool for evaluating and monitoring activities and can be used as a prevention tool and a decision maker in problem solving that occurs. Internal audit is a tool used in STMIK STIKOM Indonesia to ensure the activities at the institution have been run in accordance with the procedures they have. The institute hopes to improve management effectiveness in every field. Mismatch implementation of the procedure that occurs is a problem that must be overcome to know how effective internal audit quality is done so as to improve the effectiveness of management in solving existing problems.

From the problems disclosed, the author tries to conduct research on STMIK STIKOM Indonesia. The purpose of this study is to find out how effective the implementation of Internal Audit existing in the institution and to know the role of Internal Audit in supporting the achievement of effectiveness in STMIK STIKOM Indonesiamanagement. The research was conducted by analyzing Internal Audit system at STMIK STIKOM Indonesia. The research phase starts from literature study then continued with data collection needed in research. After all the data collected proceed with the analysis. Based on the results of questionnaires dissemination and hypothesis testing conducted, that the implementation of internal audit in STMIK STIKOM Indonesia has been
\end{abstract}


adequate and internal audit also play a role in supporting the effectiveness of the implementation of ISO 9001: 2008 quality management system. Itsconcluded that the presence of adequate internal audit will assist management in achieving the effectiveness of the implementation of ISO 9001: 2008 quality management system.

\section{Key Words: Internal Audit, Management Effectiveness}

\section{PENDAHULUAN}

Menurut Alvin (2011) audit adalah akumulasi dan evaluasi bukti tentang informasi untuk menentukan melaporkan tingkat kesesuaian antara informasi dan kriteria yang telah ditetapkan. Audit harus dilakukan oleh seorang yang kompeten dan independen. Khasharmeh (2002) menemukan bahwa auditor harus dipilih secara objektif dan tidak berdasarkan hubungan timbal balik antara dewan direksi dan auditor. Sebelumnya penelitian mendokumentasikan hubungan positif antara kualitas audit dan beberapa faktor seperti pengendalian internal.

Menurut Surat Keputusan Ketua Bapepam dan Lembaga Keuangan Nomor: Kep-496/BL/ 2008, audit internal adalah suatu kegiatan pemberian keyakinan (assurance) dan konsultasi yang bersifat independen dan obyektif, dengan tujuan untuk meningkatkan nilai dan memperbaiki operasional perusahaan, melalui pendekatan yang sistematis, dengan cara mengevaluasi dan meningkatkan efektivitas manajemen risiko, pengendalian, dan proses tata kelola perusahaan. Kuntadi (2009) apabila auditor internal berkualitas atau berperan dengan baik maka pengendalian internal akan lebih baik dan dengan sendirinya kinerja organisasi akan semakin meningkat. Soh dan Nonna (2011) dalam penelitiannya memberikan wawasan mengenai peranan dan tanggung jawab internal auditor (IA) serta fungsi dan factor-faktor yang dianggap perlu untuk menjamin efektivitasnya.Menurut Robbins dan Coulter (2007) manajemen adalah proses pengoordinasian kegiatan-kegiatan pekerjaan sehingga pekerjaan tersebut terselesaikan secara efisien dan efektif dengan dan melalui orang lain. Manajemen adalah serangkaian aktivitas manusia yang berkesinambungan dalam mencapai suatu tujuan yang telah ditetapkannya (Heene dan Desmidt, 2010).Gulick dalam Wijayanti (2008) mendefinisikan manajemen sebagai suatu bidang ilmu pengetahuan (science) yang berusaha secara sistematis untuk memahami mengapa dan bagaimana manusia bekerja bersama-sama untuk mencapai tujuan dan membuat sistem ini lebih bermanfaat bagi kemanusiaan.

Manajemen merupakan suatu profesi yang dituntut untuk bekerja secara profesional, karakteristiknya adalah para professional yang membuat keputusan berdasarkan prinsipprinsip umum, para professional mendapatkan status mereka karena mereka mencapai standar prestasi kerja tertentu, dan para profesional harus ditentukan suatu kode etik yang kuat (Schein, 2008).

Pelaksanaan Audit mutu Internal dilakukan pada STMIK STIKOM Indonesia dengan rangkaian pembentukan tim auditor, penetapan jadwal audit dan anggaran, rapat pembukaan yang dihadiri oleh pihak yang terlibat dalam pelaksanaan prosedur-prosedur, dan diakhiri dengan rapat penutupan sebagai penyampaian hasil-hasil temuan selama pelaksanaan AMI. Jika ditemukan adanya ketidaksesuaian prosedur maka membutuhkan waktu untuk melakukan tindakan koreksi atau perbaikan dan akan dibahas pada Rapat Tinjauan Manajemen (RTM).Namun hasil dari temuan AMI yang seharusnya dapat dimanfaatkan sebagai dasar dalam pengambilan keputusan belum efisien dan 
efektif untuk peningkatan Institusi.Selain itu tindakan perbaikan yang dilakukan oleh masingmasing bagian belum terdokumintasi dengan baik mengingat banyaknya perbedaan rentang waktu yang diberikan untuk melakukan tindakan perbaikan.Berdasarkan latar belakang diatas, maka rumusan masalah dalam penelitian ini adalah apakah audit internal yang diterapkan di STMIK STIKOM Indonesia sudah efektif ?dantujuan penelitian ini adalah untuk mengetahui seberapa efektif pelaksanaan Audit Internal yang ada pada institusi serta untuk mengetahui peranan Audit Internal dalam menunjang tercapainya keefektivan pada manajemen STMIK STIKOM Indonesia.

Penelitian ini dilaksanakan di Kampus STMIK STIKOM Indonesia yang beralamat di Jalan Tukad Pakerisan No. 97 Denpasar Bali.Sedangkan waktu penelitian ini adalah selama 6 bulan.Menurut Arikunto (2006:130) populasi adalah keseluruhan subyek penelitian. Populasi dalam penelitian ini adalah seluruh dosen dan karyawan di STMIK STIKOM Indonesia yang berjumlah 86 orang terdiri dari 38 orang dosen dan 48 orang pegawai. Sedangkan sampel adalah bagian dari anggota populasi.dengan demikian yang menjadi sampel penelitian ini adalah sebagian dari dosen, karyawan dan mahasiswa.Menurut sugiyono (2001, 82).Proportionate stratified random sampling merupakan teknik penentuan sampel yang digunakan bila populasi mempunyai anggota atau unsur yang tidak homogeny dan berstrata secara porposional strata yang dimaksud dalam penelitian ini yaitu dosen dan pegawai di STMIK STIKOM Indonesia, dan teknik ini dianggap cocok sebagai sumber data maka yang dijadikan sampel yaitu dosen dan pegawai di STMIK STIKOM Indonesia. Merujuk pada pendapat Unwar, H (2004) penentuan suatu sampel yang dikembangkan oleh slovin dan tidak mengalami kesulitan dalam penghitungan jumlah sampel, sebab berdasarkan rumus tersebut, ukuran sampel (n) langsung dapat diketahui hanya dengan mengetahui ukuran populasinya, artinya sampel tersebut sudah memenuhi syarat kenormalan dalam suatu penelitian. Rumus Slovin tersebut adalah, $\mathrm{n}=\frac{\mathrm{N}}{1+\mathrm{Ne} 2}$, maka dalam penelitian ini ditentukan jumlah sampel sebanyak 46 orang dari hasil $n=\frac{86}{1+86(0,1)^{2}}$ dengan error 0,1 .

Dalam menentukan porsi sampel dosen dan pegawai, didapat total sampel dengan 38 perhitungan $-\mathrm{x} 46=20$ orang (Dosen) 86

$$
\frac{46}{86} \times 46=20 \text { orang (Pegawai) }
$$

Penelitian dilakukan dengan menganalisis pelaksanaan Audit Mutu Internal pada STMIK STIKOM Indonesia. Penelitian ini terbagi atas beberapa langkah yang dapat dilihat pada gambar 3.1 berikut ini:

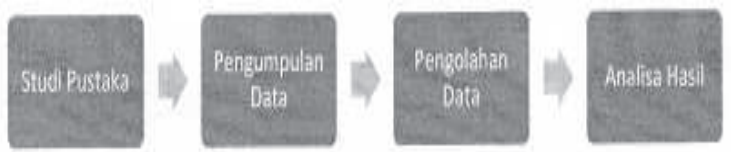

Referensi pendukung yang digunakan dalam penelitian ini berupa buku teks yang terkait dengan audit internal dan manajemen serta beberapa jurnal yang terkait dengan penelitian.

\section{PEMBAHASAN}

Dalam uji normalitas data dengan menggunakan uji Kolmogorov Smirnov untuk mengetahui apakah data berdistribusi normal atau tidak.Dari hasil pengujian, taraf signifikan peranan audit mutu internal adalah 0,372 dan taraf signifikan efektifitas manajemen adalah 0,518 . Angka-angka tersebut lebih besar dari 0,05 sehingga dapat diartikan bahwa data-data tersebut normal. Menurut Ghozali (2005) pada prinsipnya normalitas dapat dideteksi dengan 
melihat penyebaran data (titik) pada sumbu diagonal dari grafik atau histogram dari residualnya . Berdasarkan hasil dari pengujianyang dilakukan datamenyebar disekitar garis diagonal dan mengikuti arah garis diagonal, maka model regresi memenuhi asumsi normalitas dan model regresi layak dipakai untuk menganalisa peranan audit mutu internal sebagai alat bantu dalam menunjang efektifitas manajemen.

Dari Analisis deskriptif menunjukkan informasi-informasi berkaitan dengan respon responden terhadap berbagai pernyataan yang dituangkan dalam kuisioner. Berkaitan dengan analisis ini maka seluruh data penelitian ditabulasi dan diproses sedemikian rupa, sehingga dapat memberikan informasi sebagaimana yang diharapkan. Dalam analisis deskriptif akan ditunjukkan mengenai deskripsi dari masing-masing variabel beserta indikatorindikator yang mendukung variabel tersebut. Seluruh item indikator diberikan skor antara 1 sampai dengan 5, yang kemudian dirata-ratakan sehingga memperoleh satu nilai untuk nilai indikator. Semakin tinggi skor nilai yang ditunjukkan oleh indikator, maka berarti semakin baik indikator tersebut, sebaliknya semakin kecil skor nilai indikator, maka berarti semakin tidak respons responden yang diteliti.

Tabel 1.Deskripsi Variabel Peranan Audit Mutu Internal

Tanda Insikator/Item

\% Respon Responden dengan jawaban

\begin{tabular}{|c|c|c|c|c|c|c|}
\hline & & \multirow[b]{2}{*}{1} & \multirow[b]{2}{*}{2} & \multirow[b]{2}{*}{3} & \multirow[b]{2}{*}{4} & \multirow[b]{2}{*}{5} \\
\hline & & & & & & \\
\hline $\mathbf{X} 1$ & $\begin{array}{l}\text { Tujuan, kewenangan } \\
\text { dan tanggung jawab }\end{array}$ & $\mathbf{0 . 0 0}$ & $\mathbf{0 . 0 0}$ & 4,35 & 56,52 & 39,13 \\
\hline $\mathrm{X} 11$ & $\begin{array}{l}\text { Audit mutu Internal (AMI) bertanggung } \\
\text { jawab langsung kepada pimpinan Institusi }\end{array}$ & 0.00 & 0.00 & 4,35 & 63,04 & 32,61 \\
\hline $\mathrm{X} 12$ & $\begin{array}{l}\text { AMI mengemukakan bukti-bukti } \\
\text { sesuai temuan yang ada }\end{array}$ & 0.00 & 0.00 & 15,22 & 56,52 & 28,26 \\
\hline $\mathrm{X} 13$ & $\begin{array}{l}\text { Dalam AMI auditee dapat menge- } \\
\text { mukakan pendapat secara bebas } \\
\text { dan dapat dipertanggungjawabkan } \\
\text { tanpa ada pengaruh dari siapapun }\end{array}$ & 0.00 & 0.00 & 4,35 & 41,30 & 54,35 \\
\hline $\mathbf{X} 2$ & Independensi dan Objektivitas & $\mathbf{0 . 0 0}$ & $\mathbf{0 . 0 0}$ & 2.17 & 41.30 & 56.52 \\
\hline $\mathrm{X} 21$ & $\begin{array}{l}\text { Pelaksanaan AMI diawali dengan } \\
\text { Rapat Pembukaan yang wajib dihadiri } \\
\text { oleh seluruh pihak yang terlibat dalam } \\
\text { pelaksanaan prosedur-prosedur }\end{array}$ & 0.00 & 0.00 & 10.87 & 56.52 & 32.61 \\
\hline $\mathrm{X} 22$ & $\begin{array}{l}\text { Pada Rapat Pembukaan, Ketua Tim } \\
\text { Auditor akan menjelaskan hal-hal } \\
\text { yang berkenaan dengan AMI }\end{array}$ & 0.00 & 0.00 & 19.57 & 58,70 & 21,74 \\
\hline $\mathrm{X} 23$ & $\begin{array}{l}\text { AMI akan diakhiri dengan Rapat } \\
\text { Penutupan yang wajib dihadiri oleh seluruh } \\
\text { pihak yang terlibat dalam pelaksanaan AMI }\end{array}$ & 2,17 & 2,17 & 8,70 & 67,39 & 19,57 \\
\hline
\end{tabular}


X3 Kecermatan dan Kehati - hatian

X31 Tim auditor pernah diikutkan dalam pelatihan auditor

X32 Kegiatan audit mutu internal dilaksanakan untuk memotivasi auditor dalam melakukan tugasnya

X33 Auditor memiliki pengetahuan yang luas tentang sistem pengendalian internal institusi pendidikan pada umumnya

\section{X4 Jaminan Kualitas dan Pengembangan}

X41 Auditor memahami secara mendalam peraturan dan kebijakan yang dimilikiinstitusi

X42 Auditor telah berpengalaman dalam bidang audit

X43 Auditor internal mampu berkomunikasi dan bekerja sama dengan efektif dan benar

X44 Ruang lingkup AMI meliputi seluruh aktivitas Institusi

X45 Dalam AMI dilakukan audit terhadap pelaksanaan kebijakan dan prosedur yang telah ditetapkan

X46 Auditor melaporkan hasil audit dan LPMI memberikan rekomendasi kepada pimpinan mengenai kelemahan yang ditemukan

X47 AMI dapat mendukung kebenaran informasi

X48 AMI yang dilakukan dapat melakukan pemeriksaan terhadap dokumen, catatan dan laporan

$\begin{array}{ccccc}\mathbf{0 , 0 0} & \mathbf{8 , 7 0} & \mathbf{2 3 , 9 1} & \mathbf{5 8 , 7 0} & \mathbf{8 , 7 0} \\ 0,00 & 6,52 & 17,39 & 63,04 & 13,04 \\ & & & & \\ 0,00 & 2,17 & 52,17 & 41,30 & 4,35 \\ & & & & \\ 0,00 & 2,17 & 15,22 & 69,57 & 13,04\end{array}$

$\begin{array}{lllll}\mathbf{0 , 0 0} & 2,17 & \mathbf{6 , 5 2} & \mathbf{6 3 , 0 4} & \mathbf{2 8 , 2 6}\end{array}$

$\begin{array}{lllll}0,00 & 0,00 & 8,70 & 56,52 & 34,78\end{array}$

$\begin{array}{lllll}0,00 & 2,17 & 8,70 & 58,70 & 30,43\end{array}$

$\begin{array}{lllll}0,00 & 2,17 & 13,04 & 60,87 & 23,91\end{array}$

$\begin{array}{lllll}0,00 & 0,00 & 2,17 & 71,74 & 26,09\end{array}$

$\begin{array}{lllll}0,00 & 0,00 & 4,35 & 60,87 & 34,78\end{array}$

$\begin{array}{lllll}0,00 & 0,00 & 4,35 & 78,26 & 15,22\end{array}$

$\begin{array}{lllll}0,00 & 0,00 & 4,35 & 63,04 & 32,61\end{array}$

$\begin{array}{lllll}0,00 & 2,17 & 13,04 & 52,17 & 32,61\end{array}$
Dari tabel diatas tampak bahwa variable Peranan Audit mutu internal yang terdiri atas indikator (1) Tujuan, kewenangan dan tanggung jawab; (2) Independensi dan Objektivitas; (3) Kecermatan dan Kehati - hatian, (4) Jaminan Kualitas dan Pengembangan; secara keseluruhan memiliki score tinggi (setuju dan sangat setuju) berada pada kisaran 41.30 (\%) hingga 63,04\% untuk kategori setuju dan sangat setuju. 
Tabel 2.Deskripsi Variabel Efektifitas Manajemen

\begin{tabular}{|c|c|c|c|c|c|c|}
\hline \multirow{2}{*}{ Tanda } & \multirow{2}{*}{ Insikator/Item } & \multicolumn{5}{|c|}{ \% Respon Responden dengan jawaban } \\
\hline & & 1 & 2 & 3 & 4 & 5 \\
\hline Y1 & Planning & 0,00 & 1,45 & 10,14 & 59,42 & 28,99 \\
\hline Y11 & Institusi memiliki target dan tujuan & 0,00 & 0,00 & 4,35 & 63,04 & 32,61 \\
\hline Y12 & Institusi menyusun RKA setiap tahun & 0,00 & 2,17 & 13,04 & 52,17 & 32,61 \\
\hline Y13 & Institusi membuat renstra & 0,00 & 2,17 & 13,04 & 63,04 & 21,74 \\
\hline $\mathbf{Y} 2$ & Organizing & $\mathbf{0 , 0 0}$ & 1,45 & 29,71 & 52,90 & 15,94 \\
\hline Y21 & $\begin{array}{l}\text { Institusi melakukan penempatan dan } \\
\text { pembagian tugas sesuai dengan bidang }\end{array}$ & 0,00 & 2,17 & 21,74 & 54,35 & 21,74 \\
\hline Y22 & $\begin{array}{l}\text { Institusi memiliki struktur yang sesuai } \\
\text { dengan fungsi dan tata kerja }\end{array}$ & 0,00 & 2,17 & 26,09 & 54,35 & 17,39 \\
\hline Y23 & $\begin{array}{l}\text { Adanya mekanisme penggerakan } \\
\text { tugas yang dilakukan pimpinan }\end{array}$ & 0,00 & 0,00 & 41,30 & 50,00 & 8,70 \\
\hline $\mathbf{Y 3}$ & Actuating & $\mathbf{0 , 0 0}$ & 1,09 & 21,74 & 59,78 & 17,39 \\
\hline Y31 & Institusi memiliki tupoksi sesuai bagian & 0,00 & 0,00 & 30,43 & 54,35 & 15,22 \\
\hline Y32 & $\begin{array}{l}\text { Adanya pengawasan pimpinan } \\
\text { terhadap bawahan }\end{array}$ & 0,00 & 2,17 & 13,04 & 65,22 & 19,57 \\
\hline Y4 & Jaminan Kualitas dan Pengembangan & 1,09 & 15,22 & 28,26 & 41,30 & 14,13 \\
\hline Y41 & $\begin{array}{l}\text { Auditor memahami secara mendalam } \\
\text { peraturan dan kebijakan yang } \\
\text { dimilikiinstitusi }\end{array}$ & 0,00 & 4,35 & 15,22 & 65,22 & 15,22 \\
\hline Y42 & $\begin{array}{l}\text { Auditor telah berpengalaman } \\
\text { dalam bidang audit }\end{array}$ & 2,17 & 26,09 & 41,30 & 17,39 & 13,04 \\
\hline
\end{tabular}

Variabel Efektifitas Manajemen terdiri atas 4 indikator yakni (1) Planning, (2); Organizing (4); Actuating, dan (5); Controlling. Tabel diatas menunjukkan bahwa seluruh indikator mencapai score tinggi (setuju dan sangat setuju) berkisar antara 14,13 (\%) hingga $59,78(\%)$ dan score keseluruhan indikator berkisar antara 1,09 sampai 29,71. Dari keseluruhan score tersebut menunjukkan bahwa Efektifitas manajemen di STMIK STIKOM Indonesia termasuk sangat baik dan lancar, atau memiliki score tinggi. Nilai rata-rata tertinggi adalah 65.33 pada pernyataan Institusi memiliki struktur yang sesuai dengan fungsi dan tata kerja dimana hal ini berarti responden sangat memahami struktur yang berjalan selama ini sudah membantu institusi dalam melaksanakan Tri Dharma Perguruan tinggi dan jalannya sekolah tinggi secara umum dengan struktur yang pas serta memiliki fungsi yang saling membantu dan tata kerja yang dilaksanakan sudah sesuai dengan prosedur-prosedur yang diterapkan dan dievaluasi melalui kegiatan audit mutu internal. respon responden tertinggi dalam pernyataan yang menyatakan sangat tidak setuju yakni pada pernyataan Diadakannya sistem reward and punishment $1,33 \%$ atau rata rata 1,3 yang berarti bahwa ada kecenderungan penilaian dari responden tentang masih kurangnya system reward and punishment yang diberikan kepada dosen ataupun pegawai di STMIK STIKOM Indonesia. 


\section{SIMPULAN}

Secara keseluruhan pelaksanaan audit mutu internal mampu menjadi alat bantu bagi institusi dalam menambah efektifitas manajemen yang berkaitan dengan segala kegiatan yang berjalan. Proses audit mutu internal dari rapat pembukaan hingga rapat penutupan sudah dilaksanakan sesuai dengan prosedur yang dimiliki. Salah satu hasil tertinggi dari variable peranan audit mutu internal yang mendapatkan respon tertinggi adalah pada pernyataan Auditor internal mampu berkomunikasi dan bekerja sama dengan efektif dan benar, dimana ini berarti segala kegiatan audit mampu menjadi ukuran dalam mempertahankan dan meningkatkan kualitas manajemen di STMIK STIKOM Indonesia. Meski masih ada beberapa hal yang harus diperbaiki dalam efektifitas manajemen dalam hal ini yang terkait atau dapan dievaluasi melalui kegiatan audit mutu internal diantara adalah perlu pemahaman yang lebih mendalam mengenai peraturan dan kebijakan yang dimiliki institusi oleh tim auditor guna mendapatkan hasil audit yang lebih akurat terhadap informasi yang diberikan auditee.

Dalam peningkatan kualitas dengan memanfaatkan efektifitas manajemen dengan kegiaatan audit mutu internal setiap semesternya masih ada beberapa hal yang perlu diperbaiki dan menjadi bahan pertimbangan bagi institusi guna memanfaatkan hasil audit sebagai alat bantu manajemen dalam mempertahankan kualitas yang dimiliki. Belum adanya reward yang diberikan kepada dosen dan tenaga kependidikan bagi mereka yang berprestasi dan punishment yang diberikan bagi mereka yang tidak dapat menjalankan tanggung jawabnya sebagai dosen ataupun tenaga pendidik dengan baik sampai saat ini belum dilaksanakan di STMIK STIKOM Indonesia. Meskipun semua tim auditor pada pelaksanaan audit mutu internal telah tersertifikasi tetapi masih perlu diberikan pelatihan 2 yang berkaitan dengan audit untuk menambah pengalaman dan pengetahuan auditor menjadi lebih baik.

\section{DAFTAR PUSTAKA}

Alvin. A. and James. K. Loebbecke. 2000. Auditing an Integrated Approach (8th edition),Englewood Cliff, New Jersey: Prentice Hall International, Inc.

Handoko.t.2005. Manajemen personalia dan sumber daya manusia.Yogyakarta: BPFE

Khasharmeh,H.A. 2010. The Timeliness of Annual Reports in Bahrain and the United Arab Emirates.

Kuntadi, Cris. 2009. Peningkatan Kapasitas Auditor Internal Dalam Pelaksanaan Review Atas Laporan Keuangan. Majalah Dwiwulanan BPK-RI No. 119/ Agustus-September 2009/Tahun XXVIII

Meikhati,Ety. Peranan audit internal dan pencegahan fraud dalam menunjang efektivitas pengendalian internal

Robbins, S dan Coulter, M. 2007. Manajemen edisi kedelapan, Penerbit PT Indeks

Schein, Edgar h. 2004, Organizational Culture and Leadership, 3rd Edition, San Fransisco: Jossey-Bass

Terry, g, 2003, Prinsip-Prinsip Manajemen, PT.Bumi aksara. 